Ks. JAN JANICKI

\title{
POKUTA W NAUCZANIU I PRAKTYCE KOSCIOLA DWÓCH PIERWSZYCH WIEKÓW
}

Kościół poznaje ciągle na nowo dokładnie swoją naturę i przenika dogłębnie jej elementy: ludzkie i boskie, widzialne i niewidzialne, słabe i nigdy niezniszczalne. I coraz bardziej jest świadomy tego, że ,,chociaż na skutek Bożego zrządzenia jest święty i nienaganny, to jednak składa się z członków; którzy mogą się skalać winą i dlatego potrzebują ciągłego nawracania do Boga oraz odnowienia i to nie tylko wewnętrznego i osobistego, lecz także zewnętrznego i społecznego" ${ }^{1}$. Kościól od początku swego istnienia, z poczuciem wielkiej odpowiedzialności wsłuchiwal się i uypełniał Boży nakaz pokuty, zawarty w nauczaniu Chrystusa głoszącego: "Czas się wypełnił i bliskie jest Królestwo Boże. Nawracajcie się 1..Pokutę czyńcie") i wierzcie w Ewangelię" (Mk 1, 15). ,Te właśnie słowa są jakby szczytem i streszczeniem całego życia chrześcijańskiego. Do Królestua Chrystusowego możemy wejść tylko przez nawrócenie (metanoia), czyli przez wewnętrzną przemianę całego człowieka, przez którą zaczyna on myśleć, sądzić i układać swoje życie przepojony tą świętością i miłością Bożą, które w pełni czasu zostały ujawnione w Synu (Bożym) i nam w pelni udzielone" 2 .

Wierni Kościoła pierwszych wieków czuli się przynagleni wezwaniem kierowanym przez Syna Bożego do nawrócenia i Jego przykładem pokuty. Żyli ponadto dziedzictwem myśli biblijnej, przenikniętej akcentami pokutnymi ${ }^{3}$. Obok licznych wezwań ze strony proroków Starego Testamentu

'Paweł VI, Konstytucja Apostolska „Paenitemini”; cyt. za: Posoborowe Prawodawstwo Kościelne (= PPK). Wyd. E. Sztafrowski. T. 1, z. 2. Warszawa 1969, s. 69 (n. 640).

2 Tamże, cyt. jw., s. 77 (n. 650).

${ }^{3}$ S. Witek, Sakrament pojednania. Poznań-Warszawa 1979, s. 11. 
pamiętali, iż „,pokuta już przed Chrystusem uważana była jako środek osiągnięcia i zarazem jako znak doskonałości i świętości, co potwierdzają przykłady: Judyty, Daniela, Anny prorokini i wielu znakomitych mężów i kobiet, którzy w postach i modlitwach, dniem i nocą służyli Bogu z radością i weselem" 4 .

Społeczność Kościoła żyła wezwaniem do pokuty, które rozlegało się na przełomie Starego i Nowego Testamentu w nauczaniu Jana Chrzciciela i stanowiło glówny temat jego przepowiadania: „Nawróćcie się, bo bliskie jest królestwo niebieskie. (...) Wydajcie więc godny owoc nawrócenia" (Mt 3, 2. 8) ${ }^{5}$. „Wezwanie do pokuty w kontekście zapowiedzianego sądu stawia przepowiadanie Jana Chrzciciela $w$ rzędzie przepowiadania prorockiego i pozwala przypuszczać, że zasadniczy nacisk został położony na aspekt nawrócenia, które nie może sprowadzać się do pozorów. Stąd Jan wyraźnie postuluje wydanie owocu godnego pokuty" ${ }^{6}$. Jan stawia poszczególnym grupom konkretne wymagania, odpowiadające ich sytuacji (Lk 3, 10-14), tak aby ich życie bylo odtąd zgodne $\mathrm{z}$ ich postawą pokutną ${ }^{7}$.

Chrystus Pan daje przykład pokuty przyjmując chrzest Janowy (Lk 3, 21), a swoje nauczanie rozpoczyna od tego samego wezwania do pokuty, które kierował do wszystkich Jan Chrzciciel: „Nawracajcie się i wierzcie w Ewangelię" (Mk 1, 15). Jezus podjął wezwanie Jana Chrzciciela do żalu za grzechy i wewnętrznego nawrócenia, ale ukazal je w nowych wymiarach; o ile wezwanie Jana było znakiem Królestwa, które nadchodzi, o tyle wezwanie Jezusa Chrystusa stawia wszystkich wobec Królestwa, które już przyszło $w$ jego osobie ${ }^{8}$. Wezwanie grzeszników do pokuty (nawrócenia) stanowi podstawową cechę posłannictwa Jezusa ( $\mathrm{kk} 5,32$ ), który będąc Synem człowieczym odpuszcza grzechy (por. Mt 9, 6).

Posłannictwo głoszenia pokuty polegającej na nawróceniu przekazał Jezus swoim uczniom, Apostołom, którzy ,wyszli i wzywali do nawrócenia - pokuty" (Mk 6, 12). Misją Apostołów, a potem Kościoła będzie to, że $\mathrm{w}$ imię Jezusa, ,w imię Jego głoszone będzie nawrócenie i odpuszczenie grzechów wszystkim narodom, począwszy od Jerozolimy" (Łk 24, 47). Apostołowie - wzorem swojego Mistrza i Nauczyciela - rozpoczynaja dzielo ewangelizacji od wezwania do nawrócenia skierowanego do Izraela

4 Paweł VI, Paenitemini; cyl. za: PPK 1. 1, z. 2. Warszawa 1969 , s. 76 (n. 646).

${ }^{5}$ A. Suski, Wezwanie do pokuty w Nowym Testamencie. AK 70 (1977), t. 89, s. 20-23; S. Czerwik, Zarys dziejów pokutnej praktyki Kościola. W: Sakrament pokuty. Teologia. Liturgia. Pismo św. Red. A. Skowronek. Katowice 1980, s. 128; M. Czajkowski, Biblijne misterium grzechu i pojednania. W: Sakrament pokuty..., s. 209-232.

${ }^{6}$ A. Suski, Wezwanie..., s. 22.

7 S. Witek, Sakrament..., s. 12.

${ }^{8}$ A. Suski, Wezwanie..., s. 23. 
(Dz 5, 31; 20, 21) i pogan (Dz 11, 18; 20, 21), a zatem do wszystkich ludzi (Dz 17, 30). Bramą do Królestwa Bożego staje się wiara i nawrócenie potwierdzone przyjęciem chrztu, tak jak głosi św. Piotr w dzień Zesłania Ducha Świętego: „,nawróćcie się... i niech każdy $z$ was ochrzci się w imię Jezusa Chrystusa na odpuszczenie grzechów waszych" (Dz 2, 38). Gloszenie pokuty (nawrócenia) i odpuszczenie grzechów staje się jednym z podstawowych zadań Apostolów i Kościoła wszystkich czasów. Boski Zbawiciel zapewnil swemu Kościołowi władzę ,wiązania i rozwiązywania” czyli zatrzymywania i odpuszczania grzechów (Mt 18, 18; J 20, 23) ${ }^{9}$. Wzywanie do nawrócenia i uwalnianie ludzi od grzechów przez ich odpuszczenie staje się treścią przepowiadania Dobrej Nowiny i praktyki Kościoła „wszystkim narodom, począwszy od Jerozolimy" (Lk 24, 47) ${ }^{10}$.

\section{POKUTA W NAUCZANIU KOŚCIOŁA PIERWSZEGO I DRUGIEGO WIEKU}

U podstaw nauczania o pokucie i głoszenia nawrócenia w Kościele pierwszych dwóch wieków tkwiło głębokie przekonanie, że dzieło jednania czlowieka z Bogiem, dokonane raz na zawsze przez pośrednictwo Chrystusa, jest kontynuowane przez posługiwanie Kościoła ${ }^{11}$. Nauczanie św. Pawła nie pozostawiało wątpliwości: „(Bóg)... pojednal nas ze sobą przez Chrystusa i zlecił nam posługę jednania. Albowiem w Chrystusie Bóg jednał ze sobą świat, nie poczytując ludziom ich grzechów, nam zaś przekazując słowo jednania" (2 Kor 5, 18n).

Nauczanie Kościoła o pokucie i praktyka pokutna Kościola poapostolskiego (I i II w.) jest nam znana tylko w pewnej części, głównie $\mathrm{z}$ informacji znajdujących się w pismach tego okresu. Do dokumentów tej epoki należy zaliczyć: Didache (Nauka Dwunastu Apostołów), I List Klemensa Rzymskiego do Kościoła w Koryncie, List Barnaby, List św: Ignacego $\mathrm{z}$ Antiochii, List św. Polikarpa do Kościoła w Filippi, Pasterz Hermasa, II List Klemensa Rzymskiego i Pisma św. Justyna Apologety ${ }^{12}$.

${ }^{9}$ R. Loria, La Penitenza nei secoli. W: La Penitenza. Dottrina. Storia. Catechesi e Pastorale. Praca zbiorowa. Torino, brw. s. 178.

${ }^{10} \mathrm{E}$. Cothenet, Sainteté de l'Eglise et péché des Chrétiens. W: Liturgie et rémission des péchés. Conférences Saint-Serge XXe semaine d'etudes liturgiques. Roma 1975, s. 76.

${ }^{11} \mathrm{~S}$. Czerwik, Zary.s dziejów..., s. 131.

12 Wymienione dokumenty cytujemy (jeśli nie zostanie podane inne żródło) za: Pisma Starochrzescijariskich Pirarzy (= PSP), t. XLV Ojcowie Apostolscy. (Przekład A. Sw widerkówna). Warszawa 1990. 


\section{1. KONIECZNOSC POKUTY}

Wiara i przekonanie Kościoła pierwszych dwóch wieków są widoczne w nauczaniu i nawoływaniu do czynienia pokuty. DIDACHE radzi wszystkim uczestnikom Eucharystii, aby byli świętymi, gdy biorą udział w Komunii świętej. Jeśli jest inaczej, powinni czynić pokutę: „Kto święty, niech podejdzie, kto nim nie jest, niech czyni pokutę! Marana tha. Amen" (r. 10). Wydaje się, że trzeba to wskazanie odczytywać w duchu nauczania Apostoła Narodów: „Dlatego też kto spożywa chleb lub pije kielich Pański niegodnie, winny będzie Ciała i Krwi Pańskiej. Niech przeto człowiek baczy na siebie samego, spożywając ten chleb i pijąc $\mathrm{z}$ tego kielicha. Kto bowiem spożywa i pije nie zważając na Ciało (Pańskie), wyrok sobie spożywa i pije" (1 Kor 11, 27-29). Kontekst modlitwy nadaje zaleceniu DIDACHE pewien aspekt eschatologiczny: „Niechaj przyjdzie laska i przeminie ten świat: Hosanna Bogu Dawidowemu!"' (r. 10). Wezwanie do pokuty ukazane jest $w$ aspekcie eschatologicznym, zwłaszcza, że wypełniają się słowa św. Pawła: „Ilekroć bowiem spożywacie ten chleb albo pijecie kielich, śmierć Pana głosicie, aż przyjdzie" $(1 \text { Kor } 11,26)^{13}$.

Konieczność pokuty odnajdujemy również w wezwaniu do wzajemnego napominania się aż do momentu, ,dopóki (grzesznik) nie odprawi pokuty" (r. 15).

Klemens Rzymski w LIŚCIE DO KOŚCIOŁA W KORYNCIE wyraża przekonanie ówczesnego Kościoła o Bożym miłosierdziu i możliwości pokutowania. Święty Klemens naucza z całą mocą swego pasterskiego urzędu: „Oto co głosily usta Pańskie: wszystkim użycza On w miłosierdziu swym moźliwości pokutowania i tak podnosi ich na duchu wszechmocną wolą swoją" (r. 8) ${ }^{14}$. „Przebiegnijmy myślą wszystkie pokolenia, a przekonamy się, że w każdym, jednym po drugim, dawał Pan okazję do pokuty tym, którzy chcieli powrócić do Niego" (r. 7). Konieczność pokuty uzasadniają najważniejsze wydarzenia historii zbawienia. „Zwróćmy nasze oczy na krew Chrystusa i rozważmy, jak bardzo jest ona droga Jego Ojcu (1 P 1, 19): wylana za nasze zbawienie przyniosła calemu światu laskę nawrócenia" (r. 7). Do podjęcia pokuty i nawrócenia nawoływał Noe ,i ci, co go posluchali, zostali zbawieni" (r. 7); ,Jonasz zapowiedział ruinę Niniwitom, oni jednak pokutowali za grzechy swoje, a chociaż Bogu obcy, przebłagali go przecież swoimi prośbami i dostąpili zbawienia (por. Jon 3, 4-10; Mk 12, 41; Łk 11, 32)” (r. 7); „Pokutę głosili także

${ }^{13}$ Dlatego leż mówimy we Mszy śwjętej: „Glosimy śmierć Twoją, Panie Jezu, wyznajemy Twoje zmartwychwstanie i oczekujemy Twego przyjścia w chwale".

${ }_{14}$ W: M. Michalski, Antologia literatury patrystycznej. T. I. Warszawa 1975, s. 21. (Odtąd w przypisach: Michalski). 
słudzy laski Bożej natchnieni przez Ducha Świętego" (r. 8) ${ }^{15}$. Klemens Rzymski przypomina, że do pokuty wzywał ,sam Władca wszechświata, dodając przysięgę: „Na moje życie, mówi Pan, nie chcę śmierci grzesznika, lecz jego nawrócenia (Ez 18, 23; 33, 11)" (r. 8). Bóg laskawie zapewnil, iz każdemu nawracającemu się ze swych nieprawości, wybaczy: „choćby grzechy wasze były jak szkarłat, jak śnieg wybieleją, choćby były jak purpura, wybieleją jak wełna. I jeśli zechcecie mnie słuchać, będziecie spożywać dobre owoce ziemi, a jeśli nie zechcecie mnie słuchać, miecz was wytępi. Usta bowiem Pana to wyrzekły (Iz 1, 18n)" (r. 8). Św. Klemens Rzymski w uzasadnieniu swoich racji powołuje się na najbardziej wymowne teksty Pisma Świętego. To nauczanie kieruje przede wszystkim do konkretnych adresatów, sprawców buntu w Koryncie, którzy powinni upaść do nóg Pana, ,błagając Go ze łzami, aby okazal nam laskawość, pogodzil nas ze sobą i pozwolił wrócić do owego zbożnego i świętego życia w miłości braterskiej" (r. 48). Wszyscy winowajcy - naucza św. Klemens - mają ponadto poddać się władzy prezbiterów oraz przyjąć nałożoną przez nich pokutę, która umożliwi im powrót do jedności: „Wy zatem, którzy daliście początek buntowi, podporządkujcie się waszym prezbiterom (por. 1 P 5, 5), przyjmijcie karę jako drogę do nawrócenia, zginając kolana waszego serca" (r. 57). Klemens Rzymski mówi wyraźnie o pokucie i karze, jaką ,,buntownicy” winni przyjąć od hierarchii; kształt jednakże owej pokuty jest bliżej nieokreślony, poza faktem, że istnieje i że zawiera element kultyczny i wspólnotowy ${ }^{16}$.

Autor LISTU DO KOŚCIOLA W KORYNCIE wyraża przekonanie, iż to, co napisał jest nauką Bożą i dlatego ostrzega: „Jeśli ktoś jednak odmówi posłuszeństwa słowom, jakie Bóg przez nas do niego zwraca, niech wie, że niemałą ponosi winę i naraża się na niemale niebezpieczeństwo. My za grzech ten nie ponosimy odpowiedzialności” (r. 59).

Wezwanie do pokuty znajdujemy także w Listach św. Ignacego Antiocheńskiego, który z wiarą przekonuje, że to właśnie pokuta umożliwia powrót do Boga: "Gdzie jest podzial i gniew, tam Bóg nie mieszka. Wszystkim wszakże, którzy pokutują, Pan przebacza, jeśli żałując wracają do jedności z Bogiem i łączności z biskupem" ${ }^{17}$. „Jest rzeczą rozsądną czuwać i dopóki jeszcze mamy czas, czynić pokutę, aby wrócić do Boga" 18. Pokuta oznacza powrót do jedności z Bogiem i z Kościołem i jest życiem z Chrystusem: „Ci bowiem, co należą do Boga i Jezusa Chrystusa,

13 W: M. Michalski, s 21.

${ }^{16}$ L. Loria, Penitenza..., s. 185.

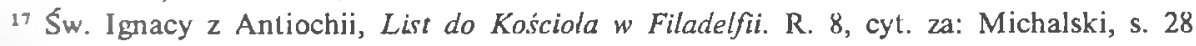
i PSP. T. XLV, s. 87.

16 Ś. Ignacy z Antiochii, List do Kościola w Smyrnie. R. 9, cyt. za: Michalski, s. 27 i PSP. T. XVL, s. 90. 
wszyscy są z biskupem. A i ci, co nawróciwszy się (pokutują) wejdą do jedności Kościoła, także będą należeć do Boga, aby mogli żyć według Jezusa Chrystusa" 19

Na konieczność pokuty wskazuje św. Polikarp w LIŚCIE DO KOŚCIOLA W FILIPPI, ubolewając nad grzechem pewnego kapłana, który wraz z żoną, z chciwości popadı w grzech bałwochwalstwa i tak znalazł się wśród chorych i błądzących. Pokuta stanowi w takiej sytuacji drogę do uleczenia i dojścia do jedności z Kościołem: „Bardzo się zatem martwię, bracia, o Walensa i o jego małżonkę. Oby dal im Pan szczere nawrócenie" (2 Tm 2, 25). (...), ,nie uważajcie ich za nieprzyjaciół" (2 Tes 3,15$)$, lecz przywołujcie ich jak członki cierpiące i zabłąkane, abyście mogli zbawić całe wasze ciało" (r. 11).

W niewielkim piśmie znanym pod nazwą DRUGIEGO LISTU DO KORYNTIAN SW. KLEMENSA wezwanie do pokuty jest przynaglającym apelem, aby przyjąć, póki czas, możliwość pokutowania daną przez miłosiernego Boga, ponieważ istnieje ona tylko do chwili śmierci: „Nawróćmy się zatem, póki jeszcze żyjemy na ziemi. (...) jak długo jesteśmy na tym świecie, żałujmy z całego serca za czyny złe, których dokonaliśmy w ciele. A może zostaniemy zbawieni przez Pana, dopóki jeszcze mamy czas na pokutę. Kiedy bowiem zejdziemy z tego świata, nie będziemy już mogli tam wyznawać swej wiary ani pokutować” (r. 8). „Tak więc, bracia, skorośmy otrzymali niemałą zachętę do pokuty, korzystając ze sposobności, dopóki jeszcze mamy Tego, który na nas czeka, nawróćmy się do wzywającego nas Boga” (r. 16). „Nawróćmy się więc (pokutujmy) z całego serca, aby nikt z nas nie zginą"' (r. 17). „Tak więc, bracia i siostry, po słowach Bożej prawdy, czytam wam to napomnienie, abyście poświęcili jak najwięcej uwagi Pismu, a wówczas i samych siebie zbawicie i tego, kto je będzie pośród was czytal. Jako zapłaty domagam się waszego nawrócenia $\mathrm{z}$ całego serca, bo przez nie zdobędziecie sobie zbawienie i życie" (r. 19).

\section{2. KATALOGI GRZECHOWW}

W pismach Kościoła I i II wieku odnajdujemy prawdziwe ,katalogi” grzechów popełnianych przez chrześcijan. NAUKA DWUNASTU APOSTOŁÓW (DIDACHE) ${ }^{20}$ przedstawiając życie chrześcijańskie w obrazie dwóch dróg: życia i śmierci, mówi wyraźnie o realnym niebezpieczeństwie „,drogi śmierci”, której znakiem są grzechy, grożące każdemu chrześcijaninowi. Grzechy są wymienione tutaj w bardzo ,szerokim” zakresie: „mors. 85 .

19 Sw. Ignacy z Antiochii, List do Kościola w Filadelfii. R. 3, cyt. za: PSP. T. XLV,

$20 \mathrm{~W}$. Rordorf, La rémission des péchés selon la Didaché. W: Liturgie et..., s. 226. 
dy, cudzolóstwa, pożądania, rozpusty, kradzieże, bałwochwalstwo, magia, czary, rabunki, fałszywe świadectwa, obłuda, nieszczerość, przebiegłość, pycha, niegodziwość, zuchwałość, chciwość, bezwstyd w mowie, zazdrość, bezczelność, duma, chełpliwość, zanik wszelkiej bojaźni (por. Rz 1, 29; Kol $3,8)$ " (r. 5). Do powyższego „,katalogu” grzechów dodane są kategorie osób, które postępują „drogą śmierci”: „prześladowcy ludzi prawych, wrogowie prawdy, milośnicy klamstwa, nieświadomi nagrody, jaką otrzyma sprawiedliwość, nie idą za dobrem ani za sądem sprawiedliwym, czujni nie na dobro, ale na zło. Obca im jest łagodność i cierpliwość, kochają marność (Ps. 4, 3), gonią za zyskiem, nie mają litości dla ubogich, obojętnie przechodzą koło udręczonych, nie znają swego Stwórcy. Mordercy dzieci, niszczą przez poronienie to, co Bóg powołał do życia. Odtrącający tych, co nic nie mają, gnębiciele ciemiężonych, obrońcy bogaczy a niesprawiedliwi sędziowie biedaków, są to grzesznicy w złym zatwardziali" (r. 5). DIDACHE nie waha się z całą mocą polecać: „Trzymajcie się, dzieci, z dala od nich wszystkich!"' (r. 5).

Nie ulega wątpliwości, iż przedstawiony przez ten dokument katalog grzechów jest wzorowany na tekstach Nowego Testamentu.

Św. Klemens Rzymski w LIŚCIE DO KOŚCIOŁA W KORYNCIE wymienia grzechy, które popełnili Koryntianie, a na które są narażeni i inni chrześcijanie: „Stąd zrodziły się zazdrość, zawiść, niezgoda i bunt, prześladowanie i zamęt, wojna i niewola”. Toteż „,powstali prostacy przeciw dostojnym, nic nie znaczący przeciw sławnym, głupcy przeciw mẹdrcom, młodzi przeciw starcom" (Iz 3, 5). Dlatego też zniknęla sprawiedliwość i pokój (Iz 59, 14), gdyż każdy zatracil bojaźń Bożą i jasny wzrok wiary. Nikt nie postępuje już według przykazań Boga (Kpł 18, 3; 20, 23), ani nie żyje w sposób godny Chrystusa, lecz wszyscy podążają za pragnieniami przewrotnych serc swoich" (r. 3). Ukazane tu, na the bardzo konkretnej sytuacji życiowej, różne rodzaje grzechów, znajdują swoje wytlumaczenie przede wszystkim w tym, iż wielu udało się uwieść „,zazdrością niesprawiedliwą i bezbożną, przez którą to "śmierć na ten świat przyszła" (Mdr 2, 24; Rz 5, 12) (r. 3).

W DRUGIM LIŚCIE DO KORYNTIAN ŚW. KLEMENSA chrześcijanin świadomy swojej słabości znajduje zachętę i jednocześnie upomnienie: „Tak więc, bracia, wypełniajmy wolę Ojca naszego Boga, a będziemy należeć do Kościoła pierwszego, Kościoła duchowego, który zostal stworzony przed słońcem i księżycem. Jeśli natomiast nie pełnimy woli Pana, do nas właśnie odniosą się te słowa Pisma: «Dom mój stał się jaskinią zbójców» (Jr 7, 11; Mt 21, 13). Lepiej zatem dla nas, bracia, należeć do Kościoła życia, abyśmy zostali zbawieni" (r. 14). Każdy, kto popelnia grzech, znieważa Kościół - poucza św. Klemens tłumacząc: „Jeśli zaś mówimy, że ciało to Kościól, a duch to Chrystus, zatem ten, kto 
znieważa ciało, znieważa zarazem i Kościół. Taki czlowiek nie będzie miał uczestnictwa w duchu, którym jest Chrystus" (r. 14). Swego rodzaju „,uzupelnieniem" katalogu grzechów jest pouczenie SW. IGNACEGO Z ANTIOCHII w Liście do Kościoła w Filadelfii: „Gdzie jest podzial i gniew, tam Bóg nie mieszka" (r. 8).

\section{3. ODPUSZCZENIE GRZECHOWW}

Dokumenty Kościoła pierwszych wieków przekazują nam bardzo cenne treści nauczania kościelnego o pokucie oraz ukazują różne elementy praktyki pokutnej. Obok przedstawionych już wezwań do pokuty oraz „katalogów grzechów” wiele mówi się o skutkach pokuty. DIDACHE poucza o „odpuszczaniu” i „nieodpuszczaniu” grzechów; nawiązując do bardzo starej tradycji żydowskiej uważa, że nie należy krytykować ani sądzić proroka przemawiającego ,,pod natchnieniem Ducha, bo każdy grzech może być odpuszczony, lecz ten grzech odpuszczony nie będzie" (r. 11). O odpuszczeniu grzechów mówi DIDACHE cytując modlitwę „Ojcze nasz" („I odpuść nam nasze winy, tak jak i my odpuszczamy naszym winowajcom") i zalecając powtarzanie tej modlitwy „trzy razy na dzień" (r. 8). DIDACHE przypomina prawdę znaną w judaizmie (Tb 4, 10; 12, 9; Syr 3, 30) jak i w chrześcijaństwie (1 P 4, 8), że dawanie jałmużny gładzi grzechy: ,Jeśli coś masz dzięki pracy rąk twoich, oddaj to na okup twoich grzechów" (r. 4).

LIST BARNABY poucza, że odpuszczenie grzechów prowadzi do nowości życia: ,kiedyśmy otrzymali odpuszczenie grzechów i złożyli naszą nadzieję w Imieniu (Pańskim), staliśmy się wówczas nowymi ludźmi, stworzonymi na nowo, od początku. Dlatego też Bóg mieszka prawdziwie w nas, w domu (serca) naszego. Jak to możliwe? Przez słowo wiary, i obietnice swoje, i swoje mądre przykazania i zalecenia swej nauki. (...) Oto duchowa świątynia wybudowana dla Pana... Pamiętaj o dniu sądu... pracując rękoma na odpuszczenie grzechów swoich" (r. 16) ${ }^{21}$.

\section{4. PRAKTYKOWANIE POKUTY A ZBAWIENIE}

Wielki apologeta chrześcijaństwa ŚW. JUSTYN podejmuje problem charakterystyczny do Kościoła końca drugiego wieku. Twierdzi mianowicie, iż ci wszyscy chrześcijanie, którzy z jakiegokolwiek powodu wracają do dawnego życia pogańskiego i wypierają się Chrystusa, to - jeśli nie będą pokutować, nie okażą skruchy i nie nawrócą się - nie mają żadnej

21 W: Michalski, s. 32 i PSP. T. XLV, s. 131. 
nadziei na zbawienie: „Bóg w swojej dobroci i miłości... uważa grzesznika za sprawiedliwego i niewinnego, jeżeli żałowal za swe winy, lecz kto z pobożności i sprawiedliwości przechodzi do bezbożności i niesprawiedliwości, jest bezbożnikiem i grzesznikiem, według tego, co powiedział Jezus: „w sytuacji, w której was zastanę, z tego was osądzę" ${ }^{22}$. Św. Justyn nie podaje dokładnego kształtu pokuty ani czasu przebaczenia win; konieczna jest jednak skrucha i żal za grzechy, by Bóg ogarnął grzesznika swoją miłością ${ }^{23}$.

Dokumentem okresu poapostolskiego, który wywarł decydujący upływ na nauczanie i praktykę pokutną Kościoła pierwszych wieków, był „PASTERZ” HERMASA. Dzieło to, napisane około połowy drugiego wieku przez Hermasa, prawdopodobnie brata papieża Piusa I, składa się z pięciu „Wizji”, dwunastu „Przykazań” i dziesięciu „Obrazów symbolicznych” („Podobieństw”). Zawiera bardzo wiele cennych danych o życiu chrześcijańskim tych czasów i stanowi dla Kościoła bardzo ważne świadectwo ducha i praktyki pokuty ${ }^{24}$.

Zasadniczym celem tego dzieła jest wezwanie grzeszników do nawrócenia i pokuty, uzasadnione grożącymi utrapieniami, zbliżającym się końcem świata i ponownym przyjściem Chrystusa. Hermas poucza przede wszystkim o Bożym milosierdziu i przebaczeniu grzechów: „Ty natomiast módl się do Boga, a On uleczy grzechy twoje (Pwt 30, 3), i całego twojego domu i wszystkich świętych" (r. 1). „Ale Pan w swoim wielkim milosierdziu ulituje się nad tobą i nad twoim domem, uczyni cię silnym i utwierdzi w chwale swojej” (r. 3). Warunkiem Bożego zmilowania jest pokuta: „Nie przestawaj więc napominać twoich dzieci, gdyż wiem, że jeśli będą pokutować z całego serca, zostaną zapisane razem ze świętymi w księgach życia" (r. 3). Hermas kieruje do „wybrańców Bożych”, zgodnie z tradycyjną nauką, wezwanie do pokuty, ale nosi ono już wyraźnie znamię pewnego ograniczenia: „Kiedy oznajmisz im te słowa, które nasz Pan mi polecil tobie objawić, wtedy zostaną im odpuszczone wszystkie grzechy, jakie poprzednio popelnili, jak również wszystkim świętym, którzy zgrzeszyli aż do tego dnia, jeżeli nawrócą się z całego serca i szczerze będą pokutować. Przysiągł Pan na chwałę swoją wobec swoich wybranych: Jeżeli po tym dniu wyznaczonym jako granica popełnią jeszcze grzech jakiś, nie znajdą już zbawienia. Kończy się bowiem czas pokuty dla sprawiedliwych. Wypel-

22 Sw. Justyn, Dialog z żydem Tryfonem, s. 47, 141, cyt. za: M. Righetli, Storia liturgica.

W. I sacramenti - I sacramentali. Milano ${ }^{2} 1959$, s. 183.

23 Tamże.

${ }^{24}$ C. Vogell, Il peccatore e la penitenza nella Chiesa antica. Torino 1967, s. 14-17; R. Loria, Panitenza..., s. 185-188. 
nily się dni pokuty dla wszystkich świętych, lecz dla pogan jest jeszcze moźliwość nawrócenia aż do dnia ostatniego" (r. 6) ${ }^{25}$.

Praktyka pokutna Kościoła pierwszych wieków pozostawała jeszcze pod wielkim wpływem owego twierdzenia Hermasa, które wyrażało jego zdecydowane przekonanie, że za grzechy popełnione po chrzcie można pokutować tylko jeden raz w życiu. Takie nauczanie Hermasa znajdujemy w czwartym „Przykazaniu”, otrzymanym od „Pasterza-Anioła Pokuty”: „Trzeba przyjąć tego, kto zgrzeszył i pokutuje, lecz nie należy tego czynić wiele razy. Dla sług Bożych jest bowiem tylko jedna pokuta" (r. 29); ,Ten kto otrzymał przebaczenie grzechów (na Chrzcie św.), powinien już więcej nie grzeszyć, ale żyć zawsze w świętości. (...) jeśli po tym wezwaniu wielkim i uroczystym (Chrzcie św.) ktoś skuszony przez szatana zgrzeszy, ma już tylko jedną możliwość pokuty. Jeśli zaś wciąż na nowo będzie grzeszyć i pokutować, nie na wiele się przyda takiemu człowiekowi, bo trudno mu będzie znaleźć życie" (r. 31).

HERMAS, przedstawiając swoją koncepcję pokuty jako objawienie udzielone mu przez Boga wyraża przekonanie, że każdy chrześcijanin, który ciężko zgrzeszyl, ma możliwość podjęcia pokuty tylko jeden raz w życiu, nie więcej ${ }^{26}$. Takie stanowisko jest uzasadnione racjami nie tyle dogmatycznymi, co raczej psychologicznymi, moralnymi i wychowawczymi. „Powodem ograniczenia pokuty do jej jednorazowości nie jest Boże zrządzenie, racja tkwi w samym grzeszniku. Jeżeli po zakończeniu procesu pokutnego ktoś ponownie popadnie $\mathrm{w}$ odpowiednio ciężką winę, poświadczy tym samym, iż nie posiada prawdziwego ducha pokuty, konsekwentnie niemożliwe staje się dalsze postępowanie pokutne" ${ }^{27}$. HERMAS twierdzi, że pokuta wraz ze swoimi skutkami: odpuszczeniem grzechów i odnową wewnętrzną jest naprawdę ,drugim chrztem”. ,powtórzeniem się" obmycia chrzcielnego dla zgładzenia grzechów. Skoro zaś nie można powtórzyć obmycia chrzcielnego, tak też nie można powtarzać pokuty ${ }^{28}$. Po chrzcie świętym zatem, określanym jako ,pokuta pierwsza" jest moźliwa jeden raz pokuta, tzw. „pokuta druga" ${ }^{29}$. Pokuta rozumiana jako ,metanoia - nawrócenie" (nie jako pokuta - sakrament) jest postawą duchową, która wyklucza chwiejność i zmienność, i jako taka jest jedna, ponieważ

25 Tłum.: Michalski, s. 35.

${ }^{26}$ Komentarze na ten temat: M. Righetti, Storia..., s. 182; C. Vogel, Il peccatore..., s. $15 \mathrm{n}$; R. Loria, La Penitenza..., s. 187; S. Czerwik, Praktyka pokutna w Kościele przez wieki. AK 70 (1977). T. 89, s. 164; B. Mokrzycki, Kościól w oczyszczeniu. Warszawa 1986, s. 29n.

${ }^{27}$ A. Skowronek, Sakrament pokuty i pojednania. „Materialy problemowe" 3 (1986), s. 55 .

${ }^{28} \mathrm{C}$. Vogel, Il peccatore..., s. 16.

${ }^{29}$ R. Loria, Penitenza..., s. 187. 
jest ona ciągła i wytrwała ${ }^{30}$. HERMAS uzasadniając istnienie pokuty poucza: „Pan ustanowił zatem pokutę jedynie dla tych, którzy zostali powolani przed tymi dniami (ostatecznymi), gdyż Pan zna serca, a wiedząc wszystko z góry zna też słabość ludzką i podstępy szatana, który będzie szkodził sługom Bożym i złość swą na nich wywierał. Będąc więc bogaty w miłosierdzie ulitował się Pan nad swoim stworzeniem i ustanowił tę pokutę, a mnie zlecil nad nią władzę” (r. 31). „Jednakże Bóg, który zna ludzką słabość i podatność na szatańskie pokusy, daje wszystkim ochrzczonym możność podjęcia pokuty tylko jeden raz. Nie oznacza to prawdopodobnie, aby HERMAS wykluczał moźliwość ponownego przebaczenia ze strony Boga; jeśli dopuszcza szansę jednorazowej pokuty za grzechy popełnione po chrzcie, czyni tak raczej z motywów psychologiczno-pedagogicznych; zastrzega się, że nie chce stwarzać chrześcijanom pretekstu do grzeszenia; wyraża przekonanie, że dopuszczenie powtarzalności pokuty czyniłoby ją tym samym nieużyteczną dla grzesznika-recydywisty. Kto bowiem wraca do grzechów świadczy o tym, że nie dokonalo się w nim prawdziwe nawrócenie $\mathrm{i}$ że jest do niego niezdolny. Pokuta po chrzcie jest jedna - to znaczy wymaga nieodwolalnej postawy odrzucenia grzechu i zwrócenia się ku Bogu. Stanowisko Hermasa tłumaczy się także jego przekonaniem o bliskim końcu świata. Pragnie on skłonić grzeszników do nieodkładania pokuty i uchronić ich przed zbytnią latwością popełniania grzechów, wskutek czego mogliby sobie zamknąć drogę do Bożego przebaczenia" ${ }^{31}$. W usta Pasterza, który daje wyjaśnienia na temat możliwości podjęcia pokuty, HERMAS wkłada zastrzeżenia, iż nie chce przez to bynajmniej dawać pretekstu do grzeszenia „tym, co mają uwierzyć ani tym, co już wierzą w Pana" (r. 31). Nawet więc możność jednorazowej pokuty po chrzcie - zdaniem Hermasa - może stać się dla niektórych ludzi okazją do grzeszenia. Tym bardziej zatem ułatwieniem popełniania grzechów byłoby dopuszczenie powtarzalności pokuty ${ }^{32}$. HERMAS przedstawia swoje spojrzenie na pokutę $w$ aspekcie eklezjalnym i eschatologicznym. Używając porównania autor „Pasterza” mówi o Kościele jak o wielkiej wieży, budowanej z lśniących, dokładnie ociosanych kamieni, białych i przystających do siebie w spojeniach. Oznaczają one Apostołów, biskupów, prezbiterów i diakonów, którzy świątobliwie żyli i uczciwie wypełniali obowiązki swego urzędu. Kamieniami przydatnymi do budowy są także ci, którzy cierpieli dla imienia Pańskiego; ci, którzy chodzą Bożymi drogami i zachowują przykazania oraz świeżo nawróceni, którzy są bez

30 Tamże.

${ }^{31}$ S. Czerwik, Wprowadzenie do odnowionej liturgii pokuty i pojednania. W: Sakrament pokuty..., s. $143 \mathrm{n}$.

${ }^{32}$ Pro. C. Vogel, Il peccatore..., s. 15 n. 
grzechu. Kamienie porzucone w pobliżu budującej się wieży oznaczają grzeszników, którzy wzbraniają się pokutować: ,nadadzą się bowiem na budowę, jeśli się nawrócą. $\mathrm{Ci}$, co mają zamiar pokutować, jeśli to uczynią, będą umocnieni w wierze pod warunkiem, że nawrócą się już teraz, w czasie, gdy wieża jest jeszcze w budowie" (r. 13). Grzesznicy, którzy podejmą pokutę staną się znowu kamieniami przydatnymi w budowie i będą uratowani. Wszyscy zaś ci grzesznicy, którzy nie podejmą pokuty w obecnym czasie budowania wieży, zostaną odrzuceni jak kamienie pothuczone, odrzucone daleko od wieży, wrzucone do ognia czy toczące się po bezdrożach. Obraz przedstawiony przez Hermasa obrazuje ostateczne losy Kościoła, które tak bardzo ściśle związane są z sytuacją na ziemi. Eschatologiczna przyszłość wspólnoty Ludu Bożego zależy od stanu życia wiernych na ziemi. Czas budowania wieży, a zatem czas obecny jest jedyną szansą podjęcia pokuty, aby stać się jeszcze ,kamieniem przydatnym w budowie".

„PASTERZ” HERMASA choć dostarcza bardzo wielu elementów pozwalających na odczytanie ducha pokuty pierwotnego Kościoła, to jednak trudno się doszukać jakiejś określonej „liturgii pokutnej" usankcjonowanej przez autorytet Kościoła ${ }^{33}$. HERMAS w zasadzie nie przedstawia roli i udziału Kościoła w ,procesie pokutnym”; ogranicza się do ukazania dialogu pomiędzy grzesznikiem i Bogiem, ponieważ jedynie Bóg odpuszcza czlowiekowi grzechy. Różne wskazania znajdujące się w „Pasterzu” każą jedynie dostrzegać udzial Kościoła, wspólnoty „świętych”, która przyczynia się do osiągnięcia przez grzesznika przebaczenia grzechów: czyny osobiste, których podjęcie wskazuje Kościól, mają ułatwić otrzymanie Bożego przebaczenia ${ }^{34}$. I w tych właśnie wskazaniach, które odczytujemy u HERMASA, dostrzega się elementy nauczania i praktyki pokutnej, która później stanie się obowiązującą praktyką w Kościele ${ }^{35}$.

2. POKUTA W PRAKTYCE KOŚCIOLA PIERWSZYCH DWÓCH WIEKÓW

Dokumenty Kościoła pierwszego i drugiego wieku zawierają bardzo ważne dla nas dzisiaj elementy nauczania o pokucie, ale także dość dokładnie przedstawiają różne praktyki pokutne tamtego czasu.

${ }^{33}$ R. Loria, La Penitenza..., s. 186; C. Vogel, Il peccatore..., 5. 16.

${ }^{34}$ C. Vogel, Il peccatore..., s. 17.

35 R. Loria, La Penitenza..., s. 186. 


\section{1. WYZNANIE GRZECHÓW}

Warunkiem powrotu grzesznika do Boga jest wyznanie grzechów, o którym mówią wyraźnie teksty ówczesnych dokumentów. Wydaje się, iz wyznanie win jawi się jako konieczność, zwlaszcza w świetle nauczania św. Jana: „Jeżeli wyznajemy nasze grzechy, Bóg jako wierny i sprawiedliwy, odpuści je nam i oczyści nas z wszelkiej nieprawości” (1 J 1,9).

W DIDACHE wyznanie grzechów ukazuje się jako element wspólnych modlitw oraz niedzielnej liturgii eucharystycznej. Wyznanie grzechów jest przygotowaniem do wspólnej modlitwy i stanowi oczyszczenie sumienia, zapewniając $w$ ten sposób owocność modlitwie: „W zgromadzeniu będziesz wyznawal swoje błędy (grzechy) i nie pójdziesz na modlitwę z nieczystym sumieniem" (r. 4). Wyznanie grzechów przed Eucharystią w „dzień Pański”, w niedzielę, jest - według „Nauki Dwunastu Apostolów" - warunkiem skutecznego uczestnictwa w sprawowaniu eucharystycznej Ofiary: „W dniu Pana gromadźcie się razem, by łamać chleb i skladać dziękczynienie, a wyznawajcie ponadto wasze grzechy, aby ofiara wasza była czysta. Niechaj nikt, kto ma jakiś spór ze swoim bratem, dopóki się nie pogodzą, nie bierze udziału w tym zgromadzeniu, aby nie zostala skalana wasza ofiara. Oto bowiem slowa Pana: Na każdym miejscu i w każdym czasie składać mi będą ofiarę czystą, ponieważ jestem Królem wielkim, mówi Pan, a imię moje budzi podziw między narodami (Ml 1, 1, 11)" (r. 14). Wyznanie swoich grzechów stanowi warunek wstępny prawdziwej modlitwy i owocnego uczestnictwa w liturgii Eucharystii. Odnotowana tu praktyka pokutna stanowi niewątpliwie pierwowzór dzisiejszego aktu pokuty, który obejmuje całe zgromadzenie liturgiczne i przygotowuje do udziału w Eucharystii ${ }^{36}$. „Członkowie niedzielnego zgromadzenia mają wyznawać swe winy, zwłaszcza popelnione przeciw braterskiej miłości, aby uchybienia przeciwko jedności nie przyniosły ujmy „,ofierze czystej", zapowiedzianej już przez proroka Malachiasza" ${ }^{37}$. Chrześcijanin dobrze rozumie, iż „lepiej bowiem wyznać publicznie grzechy niźli trwać w zatwardziałości serca, jak czynili to ci, co zbuntowali się przeciwko Mojżeszowi, słudze Bożemu. Spotkala ich kara widoczna dla wszystkich (Ps 48, 15) ${ }^{38}$. Postawa, jaką powinien zająć chrześcijanin, to postawa prośby „o darowanie win naszych i wszystkiego, cośmy uczynili z poduszczenia Przeciwnika" ${ }^{39}$.

${ }^{36}$ Uwagi odnośnie do aktu pokuty: A. Nocent, L'atto penitenziale del nuovo „Ordo Missae": sacramento o sacramentale. W: Il nuovo rito della Messa. Testo e commento. Torino 1970, s. $185-204$.

${ }^{37}$ S. Czerwik, Wprowadzenie do..., s. 141.

${ }^{38}$ Sw. Klemens Rzymski, List do Kościola w Koryncie. R. 51, cyt. za: PSP. T. XLV, s. 48.

39 Tamże. 
LIST BARNABY wymaga od uczestników wspólnej modlitwy pojednania i wyznania swoich grzechów: „Miej zło w bezwzględnej nienawiści. Sądź sprawiedliwie (Pwt 1, 16; Prz 31, 9). Nie powoduj rozłamu, lecz wprowadzaj pokój godząc walczących ze sobą. Wyznawaj grzechy twoje. Nie chodź na modlitwę z nieczystym sumieniem" (r. 19). Nawiązując do Didache (r. 4) LIST BARNABY podkreśla konieczność wspólnotowego i kultycznego wyznania grzechów: „Unikajmy wszelkiej próżności, miejmy w bezwzględnej nienawiści dzieła złej drogi. Nie próbujcie żyć w ukryciu i samotności, jakbyście byli już usprawiedliwieni, lecz zbierajcie się razem i szukajcie wspólnie tego, co dla wszystkich jest pożyteczne” (r. 4).

\section{2. WZAJEMNE PRZEBACZENIE I POJEDNANIE}

Postawa pokutna ma wymiar nie tylko wertykalny: uznanie i wyznanie swoich win wobec Boga; ma także wymiar horyzontalny: przebaczenie i pojednanie z braćmi ${ }^{40}$. „Nauka dwunastu Apostołów” (DIDACHE) domaga się: „Niechaj nikt kto ma jakiś spór ze swoim bratem, dopóki się nie pogodzą, nie bierze udziału w tym zgromadzeniu, aby nie została skalana wasza ofiara" (r. 14). Postawione tu wymaganie, jak łatwo zauważyć, jest echem nauczania Chrystusa Pana w „Kazaniu na górze”: „Jeśli więc przyniesiesz dar swój przed ołtarz i tam wspomnisz, że brat twój ma coś przeciw tobie, zostaw tam dar swój przed ołtarzem, a najpierw idź i pojednaj się z bratem swoim. Potem przyjdź i dar swój ofiaruj" (Mt 5, 23n). Tekst ten umieszcza problem jeszcze niejako ,w ramach" świątyni jerozolimskiej; DIDACHE natomiast pokazuje nam jak szybko zaadaptowano te slowa do nowej rzeczywistości, kultu chrześcijańskiego ${ }^{41}$. Potrzeba pojednania $\mathrm{z}$ braćmi, przedstawiona $\mathrm{w}$ Didache nawiązuje $\mathrm{i}$ do tego wskazania Jezusa, które zanotowal Ewangelista Marek: „A kiedy stajecie do modlitwy, przebaczcie, jeśli macie co przeciw komu, aby także Ojciec wasz, który jest w niebie, przebaczył wam wykroczenia wasze" (Mk 11, 25). DIDACHE przypominając naukę Chrystusa, potwierdza tym samym konieczność pojednania się między braćmi - uczestnikami liturgii eucharystycznej - jako warunek otrzymania Bożego przebaczenia. Potwierdzeniem tego faktu w praktyce Kościoła było przekazywanie sobie pocałunku pokoju, jako znaku wzajemnego przebaczenia i pojednania przed Komunią świętą, ale przed złożeniem darów. Św. Justyn Apologeta daje temu świadectwo w swej pierwszej ,Apologii”: „Po ukończeniu modlitw dajemy sobie nawzajem pocałunek pokoju. $Z$ kolei przynoszą przełożonemu bracia

\footnotetext{
40 W. Rordorf, La rémission..., s. 230.
}

41 Tamże, s. 231. 
chleb i kielich napełniony wodą zmieszaną z winem" (r. 65) ${ }^{42}$. Analizowany tekst DIDACHE nawiązuje zapewne i do problemu wyjaśnianego przez św. Pawła: przyjmować Ciało Chrystusa ,,godnie” znaczy ,komunikować" - przyjmować Komunię św. z należnym szacunkiem względem swoich braci, którzy także tworzą Ciało Mistyczne Chrystusa ${ }^{43}$.

\section{3. WZAJEMNE UPOMNIENIE}

W świadomości Kościoła pierwotnego istniało przekonanie o charakterze społecznym pokuty. Na wszystkich wiernych spoczywa obowiązek wzajemnego napominania i dopomagania w wysiłku nawrócenia: „Upominajcie się wzajemnie nie $w$ gniewie, lecz w pokoju, jak znajdujecie to w Ewangelii, a jeśli ktoś drugiego obrazi, niechaj nikt z nim nie mówi, niech nie usłyszy od was ani słowa, dopóki nie odprawi pokuty" (DIDA$\mathrm{CHE}$, r. 15). Wzajemne napominanie może więc być posunięte w razie potrzeby nawet do zerwania więzi z grzesznikiem, tak aby skłonić go do nawrócenia, do podjęcia pokuty.

Kościół poapostōlski był przekonany o wspólnotowej odpowiedzialności za zbawienie. Stąd też charakter społeczny ,,przebiegu" pokuty i nawrócenia: „Nawróćmy się więc $\mathrm{z}$ całego serca, aby nikt $\mathrm{z}$ nas nie zginął. Jeśli bowiem polecono nam pracować także nad tym, aby ludzi odciągnąć od bożków i uczyć ich prawdy, tym bardziej jeszcze nie wolno pozwalać na zatratę duszy, która już Boga poznała. Pomagajmy zatem sobie wzajemnie, nawet i słabych pociągając ku dobremu, abyśmy wszyscy zostali zbawieni. Nawracajmy i napominajmy jedni drugich" ${ }^{44}$. Św. Klemens, zdając sobie dobrze sprawę $\mathrm{z}$ rozbieżności istniejącej pomiędzy udziałem w liturgii i życiem, wyraźnie podkreśla rolę wspólnoty: „A nie zadowalajmy się tylko tym, że wydajemy się wierni i uważni dopóki słuchamy napomnień kapłanów, lecz także gdy powrócimy już do domu pamiętajmy o naukach Pańskich. Nie dajmy się na nowo pociągać światowym pragnieniom, ale przez ustawiczną modlitwę starajmy się postępować naprzód w przykazaniach Pana, abyśmy mając wszyscy te same dążenia, zjednoczeni weszli w życie" ${ }^{45}$. Praktykowanie wzajemnych upomnień winno być traktowane jako dobro i stanowić podstawę wdzięczności jednych wobec drugich: „Nie przyjmujmy niechętnie i nie oburzajmy się, my niemądrzy, jeżeli ktoś nas napomina i próbuje odwrócić od grzechu ku sprawiedliwości. Niekiedy bowiem postępujemy źle nic o tym nie wiedząc, ponieważ

\footnotetext{
42 Cyt. za: Michalski, s. 96.

${ }^{43} \mathrm{I}$ Kor $11,27 \mathrm{n}$ i $\mathrm{Rz} 12,3-13$.

44 Ww. Klemens Rzymski, Drugi list do Koryntian. R. 17, cyl. za: PSP. T. XLV, s. 219.

45 Tamże. R. 17.
} 
jesteśmy chwiejnego serca i małej wiary, a umysł zaciemniają nam próżne namiętności. Czyńmy zatem sprawiedliwość, abyśmy zostali w końcu zbawieni ${ }^{46}$.

\section{4. JALMUŻNA, POST, MODLITWA}

Kościól nauczył się od samego Chrystusa Pana „pozasakramentalnej” drogi zadośćuczynienia za grzechy: jałmużny, postu i modlitwy (por. Mt 6, 1-18). „Nauka Dwunastu Apostołów” zachęca do hojności w dawaniu jałmużny: „Nie wyciągaj rąk do brania i nie cofaj ich, gdy sam masz dawać (Pwt 15, 7n; Syr 4, 31). Jeśli coś masz dzięki pracy rąk twoich oddaj to na okup twoich grzechów. Nie wahaj się dawać, a gdy dasz, nie narzekaj, przekonasz się bowiem kiedyś, kto cię (za wszystko) hojnie wynagrodzi” (r. 4). Św. POLIKARP, biskup Smyrny, w LIŚCIE DO KOŚCIOLA W FILIPPI zachęca do trwania $\mathrm{z}$ Jezusem Chrystusem i naśladowania przykładu Pana. ,Mocni i niezachwiani w wierze miłujcie braci, kochajcie się wzajemnie, a zjednoczeni w prawdzie, uprzedzajcie jedni drugich $w^{-}$łagodności Pana, nikim nie pogardzajcie. Kiedy możecie czynić dobrze, nie zwlekajcie, bo ,jałmużna wyzwala od śmierci” (Tb 12, 9; por. Tb 4, 10).

DIDACHE zaleca chrześcijanom post i modlitwę ostrzegając: ,nie zachowujcie postu w tym samym czasie, co obłudnicy” oraz ,, ani nie módlcie się jak obłudnicy, lecz jak polecił Pan w swojej Ewangelii" (r. 8).

Św. Klemens Rzymski w drugim LIŚCIE DO KORYNTIAN uznaje jałmużnę za najważniejszą pośród trzech wymienionych praktyk pokutnych: „Tak więc, bracia, skorośmy otrzymali niemałą zachętę do pokuty, korzystając ze sposobności, dopóki jeszcze mamy tego, który na nas czeka, nawróćmy się do wzywającego nas Boga. (...) Dobra zatem jest jałmużna jako pokuta za grzechy. Post jest lepszy od modlitwy, a jałmużna od jednego i drugiego. Miłość zakrywa wiele grzechów (1 P 4, 8; Prz 10, 12), modlitwa zaś płynąca z czystego sumienia wybawia od śmierci. Błogosławiony każdy czlowiek, którego życie okaże się nimi wypełnione, gdyź jalmużna umniejsza ciężar grzechu"'(r. 16).

LIST BARNABY zaleca praktykowanie postu, a unikanie bezwzględnie „,wszelkich dzieł niegodziwości” (r. 4); ,,proszę (...), abyście czuwali nad sobą i nie upodabniali się do pewnych ludzi, którzy mnożą swoje grzechy mówiąc, że Przymierze należy zarówno do Żydów jak i do nas. Do nas należy, lecz Żydzi utracili je ostatecznie już w chwili, gdy je Mojżesz otrzymał. Czytamy bowiem w Piśmie Świętym: ,I był Mojżesz na górze

${ }^{46}$ Tamże. R. 19 (PSP. T. XLV, s. 220). 
poszcząc przez czterdzieści dni i czterdzieści nocy i otrzymał Przymierze od Pana, tablice kamienne zapisane palcem ręki Pana" (Wj 31, 18; 34, 28)" (r. 4). Post winien mieć formę wskazaną przez samego Boga: „Po cóż dla mnie pościcie, mówi Pan, tak że krzyk wasz rozlega się dzisiaj donośnie? Nie taki post ja uznaję, mówi Pan, nie w taki sposób pragnę, aby człowiek się umartwial. Jeśli nawet będziecie zginać waszą szyję w kabłąk, odziewać się worem i spać na popiele, i tak nie możecie nazwać tego postem miłym dla Pana" (Iz 58, 4n) (r. 3). Wskazania powyższe odnosily się do Żydów. LIST BARNABY uważa, że do chrześcijanina odnoszą się następujące słowa Bożego pouczenia: „Oto post, który ja wybieram, mówi Pan: rozerwij wszystkie kajdany zła, rozwiąż więzy przemocy, wypuść uciśnionych i podrzyj wszelkie umowy niesprawiedliwe. Podziel twój chleb z biednymi, a nagiego, jeśli ujrzysz, przyodziej, bezdomnych wprowadź do domu twego, a jeśli spotkasz nędzarza nie pogardzaj nim, nie odwracaj się od bliźnich, którzy są twymi krewnymi. Wtedy twe światło wzejdzie jak zorza, a szaty twoje wnet zajaśnieją. Sprawiedliwość iść będzie przed tobą, a chwała Pańska cię osłoni" (r. 3).

Przedstawiona wँ dość ogólnym zarysie analiza dokumentów Kościoła pierwszych wieków wskazuje na szczególne miejsce pokuty w jego nauczaniu i życiu. Zachowane teksty ukazują nam pouczenia Kościoła, który wskazuje na konieczność pokuty, przedstawia „katalogi” grzechów, mówi o odpuszczeniu grzechów i rozważa bardzo ważny problem praktykowania pokuty $w$ odniesieniu do zbawienia. Analizowane dokumenty ukazuja ponadto praktykę pokutną Kościoła, która obejmuje: wyznanie grzechów, wzajemne przebaczenie i pojednanie, braterskie upomnienie oraz jałmużnę, post i modlitwę. 